\title{
Psycho-social Factors as Predictors of Disabled Students' Academic Achievement in General Studies at the University of Ilorin, Nigeria
}

\author{
Florence Bosede Famolu
}

\begin{abstract}
For the Nigerian government to achieve a united, strong, and self-reliant nation, some variables like the socio-economic status of the parents, costly textbooks, the problem of feeding allowances for students, the low motivation of teachers due to low salaries, expensive tuition fees, the unemployment of qualified subject teachers, the lack of teaching aids, insecurity, and so on needs to be considered. Above all, psycho-social variables on the part of the students equally needs to be considered. In line with this, the researcher deemed it fit to investigate psycho-social factors as predictors of disabled students' academic achievement in General studies at the University of Ilorin. The study adopted a descriptive survey research design. The population for this study was all disabled University of Ilorin undergraduates. A questionnaire was used for data collection. Demographic characteristics of the respondents were described using percentages and the research question generated was answered using mean and rank order. All of the hypotheses formulated for this study were tested using the Mean, Standard Deviation, t-value and ANOVA. The hypotheses were tested at a 0.05 level of significance. The findings of this study revealed that there were no significant differences in the influence of psycho-social factors on disabled students' achievement in General Studies on the basis of gender. In addition, findings revealed that there was no significant difference in the influence of psycho-social factors on disabled students' achievement in General Studies on the basis of age. It was also found that there was no significant difference in the influence of psycho-social factors on disabled students' achievement in General Studies on the basis of educational level. Furthermore, findings revealed that there was no significant difference in the influence of psycho-social factors on disabled students' achievement in General Studies on the basis of the mode of entry. Hence, it was recommended that counselling units in the university should be made more accessible and friendly to disabled students so that they can easily visit the centre for guidance. With regard to their physiological, psychological and social development, more publicity is needed to create awareness for the stakeholders. Government and school management should ensure harmonious relationships for every disabled student regardless of their level or class. Students should not see age as a barrier for interacting with their colleagues.
\end{abstract}

Keywords: psycho-social factors, disabled students, academic achievement, University of Ilorin, Nigeria. 
Dr. Florence Bosede Famolu is a Lecturer in the Department of Guidance and Counselling, Faculty of Education, Osun State University, Osogbo, Nigeria. She is a member of the Counselling Association of Nigeria and is a registered member of the Teachers' Registration Council of Nigeria (TRCN). Recent publications include: Famolu F. B. \& Adelekan F. B. (2018): An Evaluation of Leadership Styles and Influence on Employees Performance in Work Organisations: A Study of Banking Industry. Journal of African Sustainable Development. 11 (8), 117-141. Published by Hummingbird Publications and Research International, Centre for Industrial Studies (CIS), S Abubakar Tafawa Balewa University, Bauchi, Bauchi State, Nigeria; and Ilesanmi O. A. Famolu F. B. Ajibola, K. S, \& Bakare, A. A. (2018): Role of Punishment as a Managerial Strategy in Nigerian Organisations. International Journal of Management Science and Entrepreneurship. 12 (5), 58-72. Published by Department of Accounting and Banking Operations. Al-Azhar University, Cairo Egypt. 


\section{Introduction}

Education is the process of transforming an individual's capabilities, skills, knowledge, and attitudes. It starts from the cradle and terminates at the grave. Individuals can acquire education through different institutions. These institutions include formal, informal and non-formal institutions. Education acquired through formal institutions is usually organized and systematic; this is the type of education given in schools, colleges, polytechnics and universities (Abulokwe, 2013). Contextually, education is the process of socializing the child to grow up as a fulfilled member of the society through an informal, formal and non-formal process.

The essence of education might not be achieved without the influence of psychosocial factors: self-concept, peer group, parents/family. Hence, the main purpose of education is to develop an individual that can be useful to himself, his family and the society in general. Development, in this case, does not mean physical development that we can always see but it also includes intellectual development that only manifest themselves in the behaviour and mental activities of the individual (Jekayinfa \& Abiri, 2010).

Socialization being a life-long process cannot be limited to family members alone. As a child grows older and becomes more mature, it becomes more necessary for external bodies to be involved in his/her life. The family is not expected to provide all of the education required by the growing child. The school, which is an established academic institution is also an important factor as the behaviour of an individual is sharpened during his/her school years to get him/her equipped for occupational socialization. In the school system, the child gets involved with a social group of "like minds" and interests as a result of the various attitudes, skills, and knowledge that is acquired through role-play. The peer group, as an agent of socialization is also an important socializing agent for the developing child. The peer group is the pivot of social change and during interaction peers, the child's life is transformed from the helpless child into a mature adult (Bierman, 2004; Adegboyega, 2019).

A peer group is defined as a small group of similarly aged, fairly close friends, sharing the same activities. In general, peer groups or cliques have two to twelve members, with an average of five or six. Peer groups provide a sense of security and they help students in building a sense of identity (Castrogiovanni, 2002). The Oxford Advanced Learners Dictionary (2001), defined a peer group as a group of people of the same age or social status. The peer group is the first social group outside the home in which the child attempts to gain acceptance and recognition. The peer group is an important influence throughout one's life but they are more critical during the developmental years of childhood and adolescence.

According to Santrock (2010), peers are the individuals who are about the same age or maturity level. Peer pressure is defined as when people of your own age encourage or urge you to do something or to keep you from doing something else, whether you personally want to do it or not. The more subtle form of peer pressure is known as peer influence and it involves changing one's behaviour to meet the perceived expectations of others (Burns \& Darling, 2002). In general, most teens conform to peer pressure about fairly insignificant things like music, clothing, or hairstyles. When it comes to more important issues like moral values, parents still remain more influential than the peer group.

According to Black (2002), peer groups provide a forum where teens construct and reconstruct their identities; at no other stage of development is one's sense of identity so unstable. Unfortunately, members of groups may accept negative labels, incorporate them in- 
to their identity, and through the process of secondary deviance, increase levels of deviant behaviour.

Achievement is an observable or measurable behaviour of a person an animal in a particular situation usually an experimental situation (Simpson \& Weiner, 2009; Adegboyega, 2018). This means that achievement measures the aspect of behaviour that can be observed at a specific period. To determine achievement, an achievement test is conducted. Singer (2011) defined an achievement test as the type of mental test in which the subject is asked to do something rather than to say something. An achievement test is the type of test which throws light on the ability to deal with things rather than symbols (Drever, 2011).

In relation to educational research, academic achievement of a student can be regarded as the observable and measurable behaviour of a student in a particular situation. For example, the academic achievement of a student in social studies includes observable and measurable behaviour of a student at any point in time during a course. In social studies, students' academic achievement consists of his scores at any particular time obtained from a teacher-made test. Therefore, we can equate academic achievement with the observed behaviour or expectation of achieving a specific statement of, or statement of educational intention, in a research. The academic achievement of students consists of scores obtained from teacher-made tests, first term examinations, and mid-semester tests.

Academic achievement is affected by a number of factors including admission points, physical challenges, social economic status and school background. Acato (2013) argues that admission points which are a reflection of previous achievement influences future academic achievement. One's educational achievement depends very strongly on the social economic status of the parents. Considine and Zappala (2012) argue that families where the parents are advantaged socially, educationally and economically foster a high level of achievement in their children.

Oyewole (2005) opined that academic achievement remains the most feasible determinant of the administrative effectiveness of school administrators. Oyedokun (2010) posited that academic achievement is a yard stick to measure the effectiveness of teachers. From another perspective, Salami (2005) opined that academic achievement is used to determine the efficiency of our educational system in terms of whether the system has been able to transform students who are admitted into the system (as inputs) into effective graduates (as outputs).

Ijaiya (2004) noted that academic standards denote what students should be able to do. It should provide explicit expectations for students at each grade level along with explicit descriptions of the content knowledge and academic skills that are required. Also, Bello (2006: p. 21) stated that the "examination is the most viable instrument to measure students in academic achievement".

According to Shavelson, Hubner and Stanton (2016), 'self-concept' is the perception that each one has about him or herself, formed from experiences and relationships with the environment, where significant people play an important role. Self-concept, as a component of human personality development has its own nature and peculiarity. Marsh and Seeshing (2007) specify the nature of the term 'self-concept' as a compendium of seven characteristics or fundamental aspects including the fact that a self-concept constitutes a psychological dimension, it is multidimensional, it has a hierarchical organization (a general self-concept and specific self-concepts) and it is stable. Harter (2008) states that a general or total selfconcept will be determined by the degree of importance that we assign to each specific com- 
ponents. If, when describing ourselves, our value judgments are satisfactory, then we obtain a positive total self-concept. In the opposite case, if we generate negative feelings, we will produce a negative total self-concept.

Several studies have examined the relationship between an individual's self-concept and academic achievement. Most of these studies support the belief that self-concept is a strong facilitator of academic achievement and that a positive or negative change in one's self-concept tends to produce a commensurate change in academic achievement or achievement (Valentine, Dubois \& Cooper, 2004; Yara, 2010). Punithavathi (2011) conducted research to investigate self-concept and academic achievement of students at the secondary level. The results of the analysis revealed a significant correlation between selfconcept and academic achievement.

Another significant factor that affects students in terms of achievement is achievement motivation. Achievement motivation is the attitude to achieve rather than the achievements themselves. It can be considered as extended person-intrinsic motivation because its reinforcement is delayed. It arises from an interaction within the person. Achievement motivation is a pattern of planning actions and of feelings connected with striving to achieve some internalized standard of excellence, as contrasted for example, with power or friendship. Chetri (2014) described achievement motivation as a desire to accomplish something difficult, to overcome obstacles and attain a high standard, to excel oneself.

Some researchers indicated that there is an awareness of the importance of family on a disabled student's academic achievement. In the view of Ajila and Otula (2000), the state of the home affects the individual since the parents are the first socializing agents in an individual's life. While the school is responsible for the experiences that make up the individual's life during school periods, parents, peer groups, self-concept, and the individual's experiences at home play tremendous roles in building the personality of the individual and making him or her what they are. Therefore, this study investigated psychosocial factors as predictors of disabled students' academic achievement in General Studies at the University of Ilorin.

\section{Research Question}

This research question was raised to guide the study:

- What is the influence of psycho-social factors on disabled students' achievement in General Studies at the University of Ilorin?

\section{Research Hypotheses}

The following null hypotheses were formulated and tested in the study:

1. There is no significant difference in the influence of psycho-social factors on disabled students' achievement in General Studies on the basis of gender. 
2. There is no significant difference in the influence of psycho-social factors on disabled students' achievement in General Studies on the basis of age.

3. There is no significant difference in the influence of psycho-social factors on disabled students' achievement in General Studies on the basis of level.

4. There is no significant difference in the influence of psycho-social factors on disabled students' achievement in General Studies on the basis of mode of entry.

\section{Research Design}

The research design that was used for the study is the descriptive survey method. A survey method is used for descriptive, explanatory and exploratory purposes and is therefore most appropriate for this study since the nature of the study entailed sourcing for data and analyzing the data to investigate psycho-social factors as predictors of disabled students' academic achievement in General Studies.

\section{Population, Sample and Sampling Technique}

According to Daramola (2006), a research population is the entire group from which the researcher is interested in gaining information and upon which a subsequent conclusion is drawn. In line with this definition, the population for this study comprised all of the 44,566 undergraduates at the University of Ilorin, while the target population for the study comprised 745 disabled students from the university.

Thus, using a purposive sampling technique, 100, 200 and 300 level students of the University of Ilorin were selected as the sample for the study. Forty (40) students were drawn from each level making a total of one hundred and twenty (120) students that were used as the respondents for this study.

\section{Instrumentation}

The instrument used for gathering information for the study was a researcher designed questionnaire titled "Psycho-social Factors as Predictors of Disabled Students' Academic Achievement in General Studies". The instrument was in two sections with section A focusing on the demographic data of the respondents while section B focused on psychosocial factors as predictors of disabled students' academic achievement in General Studies at the University of Ilorin.

\section{Psychometric Properties of the Instrument}

These measures are the validity and reliability of the instrument. 


\section{Validity}

A measuring instrument is described as valid when it measures truly and accurately what it is designed to measure (Abiri, 2006). To ascertain the validity of the instrument, the draft was given to three (3) experts in Counselling and Educational Psychology for vetting. Following corrections made by the experts, the instrument was thus adjudged to possess face and content validity.

\section{Reliability}

To ascertain the reliability of the instrument, the researcher employed the test-retest method. The instrument was administered twice on a similar sample at the University of Ilorin during an interval of two (2) weeks. The two sets of scores were then analysed using Pearson's product moment correlation. The coefficient obtained was 0.84 which was considered high and the instrument was thus adjudged reliable.

\section{Procedure for Scoring the Instrument}

The items in the instrument were structured in a way that they expressed support for psycho-social factors. The instrument was thus formatted on a four-point Likert-type scale for scoring the items. The allotment of points is as follows:

$\begin{array}{lll}\text { Strongly Agree } & \text { (SA) } & 4 \text { points } \\ \text { Agree } & \text { (A) } & 3 \text { points } \\ \text { Disagree } & \text { (D) } 2 \text { points } \\ \text { Strongly Disagree } & \text { (SD) } 1 \text { point }\end{array}$

\section{Method of Data Analysis}

Frequency count, percentages and mean ratings were used for describing the demographic data of the respondents and answering the research questions raised, while t-test and Analysis of Variance (ANOVA) were used to test the research hypotheses at a 0.05 level of significance. 


\section{Results}

A total of 120 questionnaire forms were distributed in order to elicit data to answer the research questions outlined for this study. This section presents the demographic data of the respondents. The following tables show the distribution of respondents according to the demographic information.

Table 1: Percentage Distribution of Respondents Based on Gender

\begin{tabular}{lll}
\hline Gender & Frequency & Percentage \\
\hline Male & 49 & 40.8 \\
Female & 71 & 59.2 \\
Total & $\mathbf{1 2 0}$ & $\mathbf{1 0 0 . 0}$ \\
\hline
\end{tabular}

Source: (Author's field work, 2019)

Table 1 reveals that out of the 120 respondents that participated in the study, 49 (representing $40.8 \%$ ) of the respondents were males, while 71 (representing 59.2\%) of the respondents were females. This revealed that there were more female respondents than male respondents in this study.

Table 2: Percentage Distribution of Respondents Based on Age

\begin{tabular}{lll}
\hline \multicolumn{1}{c}{ Age } & Frequency & Percentage \\
\hline 15-20 years & 35 & 29.2 \\
21-24 years & 54 & 45.0 \\
25years and above & 31 & 25.8 \\
Total & $\mathbf{1 2 0}$ & $\mathbf{1 0 0 . 0}$ \\
\hline
\end{tabular}

Source: (Author's field work, 2019)

Table 2 reveals that out of the 120 respondents that participated in the study, 35 (representing $29.2 \%$ ) of the respondents were between the age of 15-20, 54 (representing 45.0\%) of the respondents were between the age of 21-24, while 31 (representing 25.8\%) of the respondents were between the age of 26 years and above. This revealed that the majority of the respondents were between the age of 21-24 years. 
Table 3: Percentage Distribution of Respondents Based on Level

\begin{tabular}{lll}
\hline Level & Frequency & Percentage \\
\hline 100 & 40 & 33.3 \\
200 & 40 & 33.3 \\
300 & 40 & 33.3 \\
Total & $\mathbf{1 2 0}$ & $\mathbf{1 0 0 . 0}$ \\
\hline
\end{tabular}

Source: (Author's field work, 2019)

Table 3 reveals that out of the 120 respondents that participated in the study, 40 (representing $33.3 \%$ ) of the respondents were 100 level students, 40 (representing 33.3\%) of the respondents were 200 level students, while 40 (representing 33.3\%) of the respondents were 300 level students. This implies that there was an equal distribution of respondents based on level.

Table 4: Percentage Distribution of Respondents Based on Mode of Entry

\begin{tabular}{lll}
\hline \multicolumn{1}{c}{ Mode on Entry } & Frequency & Percentage \\
\hline UTME & 88 & 73.3 \\
Direct Entry & 32 & 26.7 \\
Total & $\mathbf{1 2 0}$ & $\mathbf{1 0 0 . 0}$ \\
\hline
\end{tabular}

Source: (Author's field work, 2019)

Table 4 reveals that out of the 120 respondents that participated in the study, 88 (representing $73.3 \%$ ) of the respondents were students entered through UTME (Unified Tertiary Matriculation Examinations), while 32 (representing 26.7\%) of the respondents were students entered through direct entry. This revealed that there were more UTME students than direct entry that participated in this study.

\section{Answering the Research Question}

Research Question 1: What is the influence of psycho-social factors on disabled students' achievement in General Studies at the University of Ilorin?

Table 5: Mean and Rank Order of the Influence of Psycho-social Factors on Disabled Students' Achievement in General Studies at the University of Ilorin

\begin{tabular}{|c|c|c|c|}
\hline Item & Psycho-social factors affecting academic achievement & Mean & Ranking \\
\hline 19 & $\begin{array}{l}\text { Seeing myself appreciated in the classroom encourages me } \\
\text { to do well academically }\end{array}$ & 3.70 & $1^{\mathrm{st}}$ \\
\hline 9 & I often forget what I have learnt & 3.70 & $1^{\text {st }}$ \\
\hline 20 & $\begin{array}{l}\text { I am most motivated when I see my work improve and it } \\
\text { helps my performance in school }\end{array}$ & 3.22 & $3^{\mathrm{rd}}$ \\
\hline 10 & I don't believe I can pass. So, I always perform poorly in my & 3.20 & $4^{\text {th }}$ \\
\hline
\end{tabular}


examinations

15 I am most motivated when I am noticed by others

$3.15 \quad 5^{\text {th }}$

5 I don't have a phobia for any of my courses and this helps

$3.12 \quad 6^{\text {th }}$

me to do better academically

11 Doing things like sports, gym, and dance helps my reading $\quad 3.08 \quad 7^{\text {th }}$

$1 \quad$ I'm always positive about myself and this has always helped $\quad 3.07 \quad 8^{\text {th }}$ me academically

16 I am most motivated when I am confident that I can do my $\quad 3.05 \quad 9^{\text {th }}$ schoolwork

6 I can't follow lessons easily

$3.04 \quad 10^{\text {th }}$

12 The need to always be appreciated by my friends motivates $\quad 2.85 \quad 11^{\text {th }}$ me to do better academically

2 I study hard for my test and it affects my academics positively

17 I am most motivated to do well academically when I am becoming better at my work

$7 \quad$ I do not give up easily when I'm faced with difficult questions in my school work and this always helps me academically

13 I am most motivated when I am in charge of a group and it helps with my academic achievement

3 I get frightened when I'm asked questions and it always has effect on my academic achievement

18 I am most motivated academically when I solve a problem

$2.85 \quad 11^{\text {th }}$

$2.7513^{\text {th }}$

$2.70 \quad 14^{\text {th }}$

$2.32 \quad 15^{\text {th }}$

$2.3216^{\text {th }}$

$2.20 \quad 17^{\text {th }}$

$2.20 \quad 17^{\text {th }}$ examinations and this helps me academically

14 Competing with my classmates motivates me to do well $\quad 1.84 \quad 19^{\text {th }}$ academically

$4 \quad$ I'm usually interested in my school work and it has a $\quad 1.74 \quad 20^{\text {th }}$ positive effect on my academic achievement

Source: (Author's field work, 2019)

Table 5 presents the mean and rank order of the respondents on influence of psycho-social factors on disabled students' achievement in General Studies at the University of Ilorin. The table indicates that items 19 and 9 which state that "Seeing myself appreciated in the classroom encourages me to do well academically, and I often forget what I have learnt" ranked 1st with a mean score of 3.70. Item 9 which states that "I am most motivated when I see my work improve and it helps my performance in school" ranked 3rd with a mean score of 3.22. Ranked $4^{\text {th }}$ is item 10 which states that "I don't believe I can pass. So, I always perform poorly in my examinations", with a mean score of 3.20. On the other hand, item 15 which states that "I am most motivated when I am noticed by others" ranked 5th with a mean score of 3.15. Item 5 which state that "I don't have phobia for any of my courses and this helps me to do better academically" ranked 6th with a mean score of 3.12. Item 11 which states that "Doing things like sports, gym, and dance helps my reading" with a mean score of 
3.08 ranked $7^{\text {th }}$. Item 1 which states that "I'm always positive about myself and this has always helped me academically" with a mean score of 3.07 ranked $8^{\text {th }}$. Since fourteen out of the twenty items in the questionnaire ranked above the mid-mean score of 2.50 , then it can be said that the suggested items in the questionnaire are psycho-social factors which have an influence on disabled students' achievement in General Studies at the University of Ilorin.

\section{Hypotheses Testing}

Ho1: $\quad$ There is no significant difference in the influence of psycho-social factors on disable students' achievement in General Studies on the basis of gender.

Table 6: Mean, Standard Deviation and t-test Analysis of difference in the influence of psycho-social factors on disabled students' achievement in General Studies on the basis of gender

\begin{tabular}{|c|c|c|c|c|c|c|c|}
\hline Gender & $\mathrm{N}$ & Mean & $\mathrm{SD}$ & $\mathrm{df}$ & Cal.t-value & Sig. & Decision \\
\hline Male & 49 & 56.1633 & 4.43164 & 118 & .070 & .734 & $\begin{array}{c}\text { Not } \\
\text { Rejected }\end{array}$ \\
\hline Female & 71 & 55.8873 & 4.31459 & & & & \\
\hline
\end{tabular}

Source: (Author's field work, 2019)

As shown on Table 6, males had mean score of 56.1633 with a standard deviation 4.43164 , while females had mean score of 55.8873 with a standard deviation of 4.31459 . The calculated t-value was .070 while its calculated significance value was 734 of df 2/118 at an alpha level of 0.05 . On this basis, the null hypothesis was therefore not rejected. This means that there was no significant difference in the influence of psycho-social factors on disabled students' achievement in General Studies on the basis of gender. The reason was that the calculated significance value (.734) was greater than the 0.05 alpha level $(\rho>0.05)$.

Ho2: $\quad$ There is no significant difference in the influence of psycho-social factors on disable students' achievement in General Studies on the basis of age.

Table 7: ANOVA summary of difference in the influence of psycho-social factors on disabled students' achievement in General Studies on the basis of age

\begin{tabular}{ccccccc}
\hline Source of Variance & Sum of Squares & $\mathbf{d f}$ & Mean Square & F & Sig. & Decision \\
\hline Between Groups & 2.624 & 2 & 1.312 & & .934 & Not Rejected \\
Within Groups & 2245.376 & 117 & 19.191 & .068 & & \\
\hline Total & $\mathbf{2 2 4 8 . 0 0 0}$ & $\mathbf{1 1 9}$ & & & & \\
\hline
\end{tabular}

Source: (Author's field work, 2019) 
Table 7 shows an F-value .068 with a calculated significant .934 at a 0.05 alpha level. Since the calculated significance .934 is greater than 0.05 alpha level, the hypothesis is thus not rejected. This implies that there was no significant difference in the influence of psychosocial factors on disabled students' achievement in General Studies on the basis of age.

Ho3: $\quad$ There is no significant difference in the influence of psycho-social factors on disable students' achievement in General Studies on the basis of level

Table 8: ANOVA summary of difference in the influence of psycho-social factors on disable students' achievement in General Studies on the basis of level

\begin{tabular}{ccccccc}
\hline Source of Variance & Sum of Squares & Df & Mean Square & F & Sig. & Decision \\
\hline Between Groups & 26.600 & 2 & 13.300 & & .498 & $\begin{array}{c}\text { Ho3 } \\
\text { Not Rejected }\end{array}$ \\
Within Groups & 2221.400 & 117 & 18.986 & & & \\
\hline Total & $\mathbf{2 2 4 8 . 0 0 0}$ & $\mathbf{1 1 9}$ & & & & \\
\hline
\end{tabular}

Source: (Author's field work, 2019)

Table 8 shows an F-value .701 with a calculated significant .498 at a 0.05 alpha level. Since the calculated significance .498 is greater than the 0.05 alpha level, the hypothesis is thus not rejected. This implies that there was no significant difference in the influence of psychosocial factors on disabled students' achievement in General Studies on the basis of level.

Ho4: There is no significant difference in the influence of psycho-social factors on disabled students' achievement in General Studies on the basis of mode of entry

Table 9: Mean, Standard Deviation and t-test Analysis of difference in the influence of psycho-social factors on disable students' achievement in General Studies on the basis of mode of entry

\begin{tabular}{|c|c|c|c|c|c|c|c|}
\hline Mode of Entry & $\mathrm{N}$ & Mean & SD & $\mathrm{df}$ & Cal.t-value & Sig. & Decision \\
\hline UTME & 88 & 55.9318 & 4.34648 & \multirow[t]{2}{*}{118} & .228 & \multirow[t]{2}{*}{.777} & \multirow[t]{2}{*}{$\begin{array}{c}\text { Not } \\
\text { Rejected }\end{array}$} \\
\hline Direct Entry & 32 & 56.1875 & 4.40994 & & & & \\
\hline
\end{tabular}

Source: (Author's field work, 2019)

As shown on Table 9, UTME had a mean score of 55.9318 with a standard deviation 4.34648, while Direct Entry had a mean score of 56.1875 with a standard deviation of 
4.40994. The calculated t-value was 118 , while its calculated significance value was .777 of df $2 / 118$ at an alpha level of 0.05 . On this basis, null hypothesis three was therefore not rejected. This means that there was no significant difference in the influence of psycho-social factors on disabled students' achievement in General Studies on the basis of the mode of entry. The reason was that the calculated significance value $(.777)$ was greater than 0.05 alpha level $(\rho<0.05)$.

\section{Discussion of the Findings}

All of the items in the questionnaire are found to be the psycho-social factors which have an influence on disabled students' achievement in General Studies at the University of Ilorin. The first hypothesis stated that there was no significant difference in the influence of psycho-social factors on students' achievement in General Studies on the basis of gender. The finding was in agreement with that of Bode (2010) in Ghana which showed that gender did not play a role in psycho-social variables affecting the academic performance of secondary school disabled students. In South Africa, another study by Meece and Jones (2005) also revealed that gender differences did not influence students' standardized test scores. However, Haist et al., (2000) showed that peer influence is more favourable to academic performance of male students than female disabled students in certain settings while females outperformed males in other settings. A study by Hedges and Newell (2008) showed male students outperformed female students in science, but in reading and writing, female students did much better. However, educational statistics have indicated that female students are outperforming their male counterparts at all levels of the education system and attaining higher qualifications. After analyzing more than a million graduating students, Woodfield and Earl-Novell (2006) observed that female students did better than male students. They attributed this partly to female students being more academically responsible and thus less likely to be absent from lessons.

Furthermore, it was found that there was no significant difference in the influence of psycho-social factors on disabled students' achievement in General Studies on the basis of age. In contrary, a study by Lier and Cooky (2005), revealed that age had an influence on the level of maturity and manner of interaction of students with disabilities which indirectly affected their academic achievement.

Another finding revealed that there was no significant difference in the influence of psycho-social factors on disabled students' achievement in General Studies on the basis of level. Thus, students irrespective of their level, experience similar influences of psycho-social factors on their academic achievement.

Further findings revealed that there was no significant difference in the influence of psycho-social factors on students' achievement in General Studies on the basis of mode of entry. The finding is in consonance with that of Buhari (2013) who found that regardless of the ways through which students enter schools, 90 percent of them exhibit a similar psychosocial experience. 


\section{Conclusion}

This study investigated psycho-social factors as predictors of disabled students' academic achievement in General Studies at the University of Ilorin. Variables such as gender, age, level, and mode of entry were used to determine the difference, or otherwise, among the respondents. Hence, findings of the study revealed that gender, age, level, and mode of entry did not have any significant influence on psycho-social factors as predictors of disabled students' academic achievement in General Studies at the University of Ilorin.

\section{Recommendations}

Based on the findings of the study, the following recommendations were made:

1. Counselling units in the university should be made more accessible and friendly to disabled students so that they can easily visit the centre for guidance. Their physiological, psychological and social development needs require more publicity to create awareness for stakeholders.

2. Government and school management should ensure harmonious relationships between every student regardless of their level or class.

3. Students should not see age as a barrier for interacting with their colleagues. 


\section{References}

Abdul, P.D. (2000). "Peer-model attributes and children's achievement behaviors". Journal of Educational Psychology, 79, 54-61.

Abulokwe, C. (2013). Declining Quality Education in History of Education in Nigeria. NPS. Ibadan: Educational Publishers Ltd.

Acato O.A. (2013). "Social Analysis of Moral Malpractice Challenging Education Sector in Nigeria”. British Journal of Education, Society \& Behavioural Science, 4(7): 965-986.

Adegboyega, L.O. (2018). "Influence of achievement motivation on Nigerian undergraduates' attitude towards examination”. International Journal of Instruction, $11(1), 77-88$.

Adegboyega, L.O. (2019). "Challenges and adjustment needs of students with special needs in Ilorin metropol in Kwara State". Ife PsychologIA. 27 (1); 61-74.

Aremu, S. \& Sokan D.O. (2003). Juvenile Delinquency: Ado-Ekiti Secondary Schools as case Study, Causes and Solutions. An Unpublished B.Sc Project, Department of Sociology and Anthropology, Ondo-State University, Ado Ekiti.

Bierman, V. (2004). "Latino High School Students': A psych-socio cultural perspective on coping mechanisms and their influences on academic performance." Hispanic Journal of Behavioural Sciences, 19 (3) 301- 317.

Black, V.O (2002). "An appraisal of educational standard in Nigerian public primary schools.” Benin. Journal of Social Sciences, 17 (1)53- 62.

Burns, F.A. \& Darling J. (2002). Self-concept. Hillsdale, NJ: Erlbaum.

Castrogiovanni, A.M. (2002). "The academic resilience of Mexican American High School students”. Hispanic Journal of Behavioural Sciences, 19 (3), 301-317.

Considine, L.\&Zappala, S. (2012). The Place of Private Participation in Higher Education: A Periscope on Private Universities in Nigeria. Centre for Population and Environmental Development (CPED): Benin City.

Daramola, S. 0. (1991) Research method and statistical analysis in education. Ado-Ekiti. Petoa Educational Publisher.

Darling, N., \& Steinberg, L. (1993). "Parenting style as context: An integrative model." Psychological Bulletin. Vol. 113. pp. 487-496.

Dornbusch, S.M., Ritter, P.L., Leiderman, P.H., Roberts, D.F., \& Fraleigh, M.J. (2007). "The relation of parenting style to adolescent school performance". Child Development, 58 (5), 1244-1257.

Drever, V. (2011) "Cross-cultural validation of the Inventory of School Motivation (ISM)". Journal of Applied Measurement, 2, 134-152.

Dwairy, R., \& Menshar, S. (2006). "The impact of parental support, behavioral control, and psychological control on the academic achievement and self-esteem of African American and European American adolescents". Journal of Adolescent Research, 18, 523-541. doi: $10.1177 / 0743558403255070$

Efobil, A.C. \& Nwokolo, C.N. (2011). "Incidence of bullying among secondary school students in Anambra State, Nigeria: Implication for counseling." International Journal of Research in Counseling and Sports Science, IJORECS, 2(1), 106-116.

Elder, G.A. (1984). "Families, kin, and the life course: A sociological perspective". In R. Park (Ed.), Advances in child development research: The family. (pp. 80-136). Chicago: University of Chicago Press. 
Elliot, A.J. \& Dweck, C.S. (2005). Handbook of competence and motivation, Guilford Press, Cambridge University, New York.

Enochs, J., \& Roland, A. (2006). "Models of parenting: Implications for adolescent wellbeing within different types of family contexts. " Journal of Adolescence, 18, 253270. doi:10.2466/PR0.93.7.823

Harter, B.J. (2008). "Self-Efficacy: An essential motive to learn". Contemporary Educational Psychology, 25, 82-91.

Ijaiya, L.H. (2004). “Affective variables and mathematics education”. Elementary School Journal, 84: 558-581.

Jane, V.V. (2012). "Declining quality of intellectual output in Nigeria's tertiary institutions of learning: The underlining existential factors". Journal of Education and Practice, 4(11): 39-42.

Jekayinfa, A. \& Abiri, A. (2010). "Falling Standard of Education: A Case of Ekiti State College of Education". European Scientific Journal, 9(19): 112-122.

Maccoby, E E. \& Martin, J. A. (2003). "Socialization in the context of the family: Parentchild interaction." Handbook of child psychology: Vol. 4. Socialization, personality, and social development (4th ed.). New York: Wiley.

Mapes, R.R. (2008). "The socialization of fear of failure in Japan and the United States". The Science and Engineering Journal. Vol. 69(5-B), 3320.

Marsh, R. \& Seeshing, U. (2007). "Falling Standard of Education in Nigeria: Causes and Solution". Studies in Education, 14(1);

Ofili, A. (2012). "Predictors of academic performance during early adolescence: A contextual view". International Journal of Behavioral Development, 27, 541-548.

Oyedokun, D. H. (2010). Elf-Beliefs and School Success: Self-Efficacy, Self-Concept, And School Achievement in R. Riding \& S. Rayner (Eds.), Perception. (pp. 239-266). London: Ablex Publishing.

Oyewole, M. D. (2005). "The role of self-efficacy and self-concept beliefs in mathematical problem-solving: A path analysis". Journal of Educational Psychology, 86, 193-203.

Salami F. (2005). "Self-efficacy beliefs, motivation, and achievement in writing: A review of the literature". Reading \& Writing Quarterly, 19 (2), 139-158.

Santrock, S. (2010). "Causes, correlates, and the functional role of global self-worth: A lifespan perspective". In Sternberg, R.J., and Kolligian, J. (eds.), Competence Considered. Yale University Press, New Haven, CT, pp. 67-97.

Shavelson, U., Hubner, I. and Stanton, R.W. (2016). "The Self-efficacy Scale". Construction and Validation Psychological Report, 5, 663- 671.

Shobhna, B. \& Rekha, C.C. (2009). Teaching, Nigeria's 'profession of last resort'. Daily Trust. Available on http://www.dailytrust.com.ng/news/education/teaching-nigeria-sprofession of- lastresort/ 80667.html

Simpson, A. \& Weiner O.O. (2009). The effectiveness of counseling techniques on mental models in value clarification and success orientation of adolescents in selected secondary schools in Lagos, Nigeria. Unpublished doctoral dissertation. University of Lagos. Lagos

Singer, R. (2011). "Subject-specific components of academic self-concept and self-efficacy". Contemporary Educational Psychology, 16, 331-345

Wanjobi, J.B. (2011). "Analysis of Poor Performance of Senior Secondary Students in Chemistry in Nigeria". African Research Review: An International Multidisciplinary Journal, Ethiopia, 6(4): 324-334. 